\title{
ESTUDO DAS CONDIÇÕES HIDROGEOLÓGICAS E HIDROQUÍMICAS DOS AQÜIIFEROS DA REGIÃO DE BIRITINGA - PATAÍBA (BA) UTILIZANDO MÉTODOS GEOFÍSICOS ELÉTRICOS
}

\author{
IARA B. DE OLIVEIRA* e OLIVAR A.L. DE LIMA**
}

\begin{abstract}
Drill holes which tapped the aquifers of the Ilhas and Massacará Groups in many places of the Tucano Sedimentary Basin produce water with a high content of dissolved salts. In order to optimize a procedure to determine the two dimensional extent of the salt water occurrence, as well as to contribute to the understanding of possible mechanisms responsible for this salinization, geophysical studies were made in the Biritinga-Paraíba area in the State of Bahia. Twenty eight (28) vertical electrical soundings, electrical logs of 13 wells and chemical analysis of 35 samples of groundwater allowed to determine the structural configuration of the Ilhas-Massacará aquifer system in the region, and to estimate the influence of this configuration on the chemical characteristics of the groundwater. In the study region the system consists of a vertical sequence of sandstone and shale layers dipping SE, which are longitudinally sectioned by gravity faults in a sequence of horsts and grabens. In the horsts where the system contains a high shale-sandstone proportion, the water is more salty. Furthermore, some of the structural blocks have shown an increase of water salinity with depth. These facts seem to indicate that ionic filtering by the shales in the system and a process of mixing and hydrodynamic dispersion along the faults are the main controllers of the characteristics of the groundwater. The results also indicate that under favorable conditions, information about the block structure system and water characteristics can be inferred from surface electrical soundings.
\end{abstract}

INTRODUÇÃO Os grupos Ilhas e Massacará na Bacia Sedimentar de Tucano são constituídos basicamente de arenitos e folhelhos intercalados, podendo conter interestratificações de siltitos e calcários em leitos médios e finos (Soares \& Pereira 1966, Chignone 1979). Eles têm sido considerados na literatura como portadores dos melhores aqǘferos da bacia, em função da presença de espessos pacotes de arenitos (Leite 1964, Ferreira 1965). Entretanto, em vários locais dessa bacia, poços perfurados para o abastecimento de cidades, vilas e fazendas da região têm produzido águas com elevados teores de sais dissolvidos não utilizáveis para consumo humano. Assim, tem-se registrado a produção de água salinizada em poços perfurados nas proximidades de várias cidades da região, tais como em Araci, Biritinga, Pataíba, Sátiro Dias e Teofilândia, entre outras (CERB 1975, 1980, 1981, 1983). Não obstante, as extensões dessas ocorrências não estão definidas assim como os mecanismos dessa salinização não estão ainda completamente entendidos.

Neste trabalho, foram empregados os métodos geofísicos elétricos em seus procedimentos de sondagem elétrica vertical e de perfilagem elétrica de poço, em combinação com análises físico-químicas de amostras de água subterrânea, para se obter uma avaliação geo-hidrológica e hidroquímica dos aqüíferos dos grupos Ilhas e Massacará, na região de Biritinga-Pataíba (Ba) (Fig. 1). Esta avaliação consistiu principalmente na determinação da geometria tridimensional dos corpos de arenitos, dos valores de resistividades das diferentes litologias, das resistividades das águas subterrâneas e das porosidades das camadas de arenitos investigadas, além de estimativas qualitativas sobre a proporção de argila em cada camada. Além disso, procurou-se definir a extensão em profundidade e na superfície do terreno, das zonas de ocorrência de águas salinizadas nesse sistema, assim como se tentou identificar os mecanismos atuantes no processo de salinização. Para tanto, foram realizadas 28 sondagens elétricas verticais utilizando a configuração Schlumberger, estudados perfis de eletroindução e microperfis elétricos de 13 poços da região perfurados para água subterrânea e estudos de petróleo, e coletadas 25 amostras de água de subsuperfície para análises físico-químicas.

A região de Biritinga-Pataíba foi escolhida para a realização deste estudo tendo em conta a quantidade e a diversidade de informações de poços disponíveis. Assim, para o suprimento das cidades de Biritinga e de Serrinha (Fig. 1), existem perfurados 16 poços, dos quais sete foram perfilados eletricamente com indução e/ou microperfil. Do total de poços perfurados, cinco foram abandonados por produzir águas salinizadas. Dos dois poços perfurados para a vila de Pataíba, dos quais o CERB II dispõe de perfil elétrico, um também foi abandonado e o outro tem uso restrito. Cópias dos perfis elétricos desses poços foram fornecidas ao Programa de Pesquisa e Pós-Graduação em Geofísica da UFBa pela Companhia de Engenharia Rural da Bahia (CERB). Além desses poços de água, foram cedidos pela Petrobrás cópias dos perfis elétricos de cinco poços de exploração de petróleo perfurados na área.

FEIÇÕES GEOLÓGICAS GERAIS A região estudada (Fig. 1) possui uma área de aproximadamente $400 \mathrm{~km}^{2} \mathrm{e}$ situa-se na borda sudoeste da Bacia de Tucano. Esta bacia corresponde a um graben assimétrico de origem tensional preenchido de sedimentos clásticos continentais de Idade Jurássica a Terciária pertencentes ao Supergrupo Bahia (Viana et al. 1971). Seu substrato mergulha regionalmente

* Instituto de Física-UFBA. CEP 40000, Salvador, Bahia, Brasil

** Programa de Pesquisa e Pós-Graduação em Geofísica e Instituto de Geociências da UFBA. Rua Caetano Moura, 123, CEP 40000, Salvador, BA, Brasil 


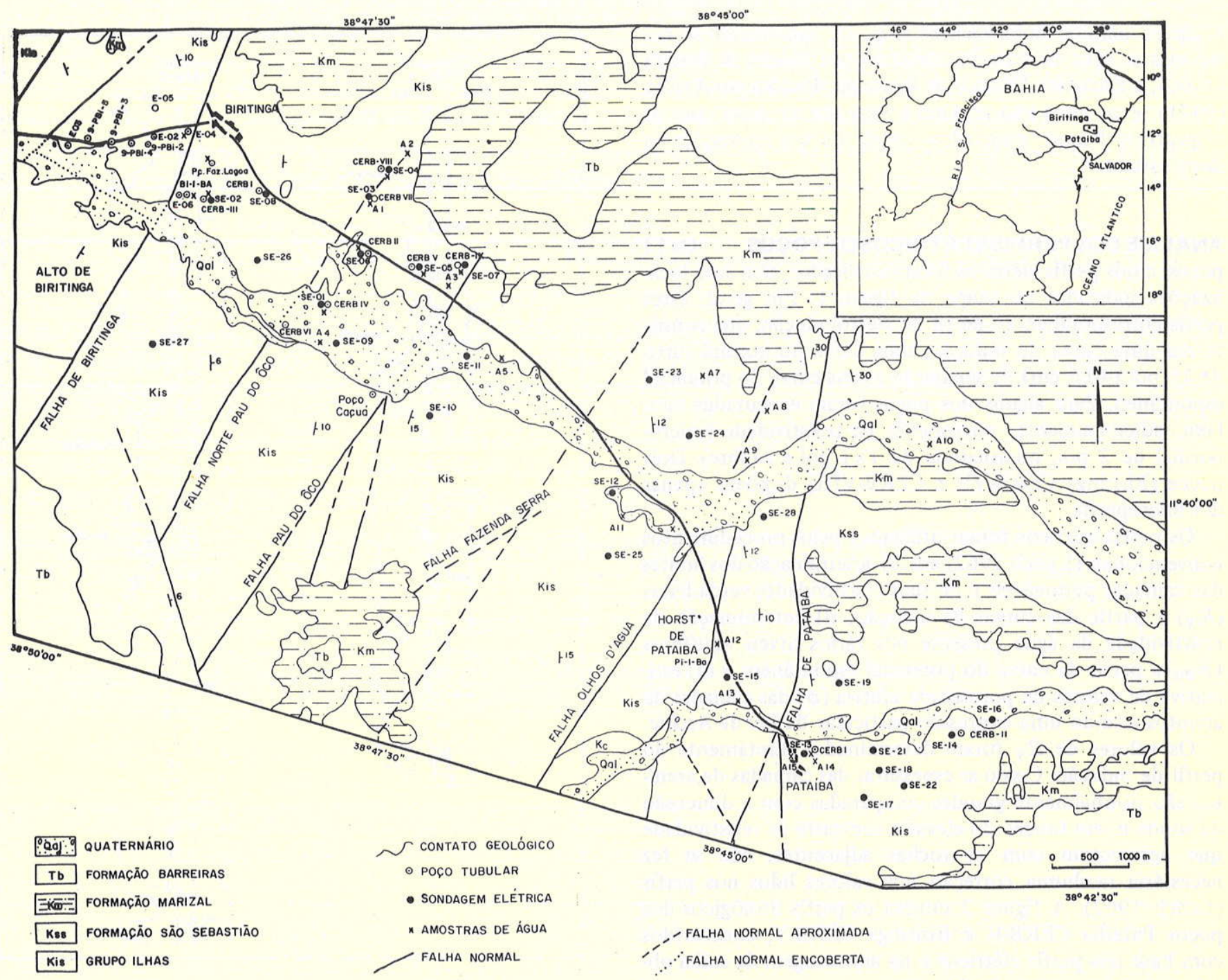

Figura 1 - Mapa geológico da região de Biritinga-Pataiba contendo a localização dos poços estudados, dos centros das sondagens elétricas e dos pontos de amostragem de água

para leste e, juntamente com o pacote sedimentar, está bastante falhado, o que compartimentou a seqüência em conjuntos de blocos estruturais.

O Supergrupo Bahia compreende uma sucessão de folhelhos, arenitos, siltitos e calcários entre os quais se incluem aqueles dos grupos Ilhas e Massacará, objetos principais deste trabalho.

O Grupo Ilhas da Bacia do Tucano é informalmente subdividido em três unidades (Soares \& Pereira 1966), designadas neste trabalho pelas letras A, B e C, respectivamente, da base para o topo.

A unidade A é constituída de arenitos argilosos, feldspáticos e micáceos, interacamados com folhelhos e siltitos geralmente calcíferos e contém, ainda, finos leitos de calcário. Os folhelhos, particularmente dominantes nessa unidade, são calcíferos e carbonosos com muita pirita disseminada.

A unidade B é constituída de espessos leitos de arenitos argilosos, calcíferos, bem compactados e cimentados, intercalados com folhelhos calcíferos, calcários e bancos de conglomerados com grandes seixos de quartzo leitoso.
A unidade C compreende também uma seqüência de arenitos, folhelhos e calcários intercalados, todavia com uma maior proporção de arenitos. Os arenitos são caulínicos, argilosos e micáceos; e os folhelhos, carbonosos e calcíferos e contêm finas camadas de calcários.

O Grupo Massacará engloba os sedimentos da Formação São Sebastião, que, na Bacia de Tucano, não está subdividida em outras unidades (Soares \& Pereira 1966). Esta formação é de composição dominantemente arenítica de granulação média e fina, e contêm intercalações de folhelhos e de siltitos.

Ocorrem ainda, na área estudada, as formações Marizal e Barreiras, ambas de constituição areno-argilosa, que representam coberturas das unidades descritas. Dispõem-se geralmente na forma de tabuleiros ou em afloramentos isolados e, em função também de suas pequenas espessuras, não constituem aquíferos importantes na região. Sedimentos de distribuição ainda mais restrita compreendem os aluviões quaternários dos valoes do Rio Inhambupe e de seus tributários (Fig. 1).

As feições tectônicas mais proeminentes na região são as falhas normais que delimitam altos e baixos estruturais 
e alguns amplos dobramentos (Fig. 1), salientando-se entre eles o Alto de Pataíba, descrito por Soares \& Pereira (1966); a Estrutura Dômica de Biritinga, descrita por Airaújo (1971); e os altos Pau do Oco e Fazenda da Serra com os respectivos baixos associados, revelados em conseqüência deste estudo.

\section{ANÁLISE DOSPERFIS ELÉTRICOSDE POÇOS OS 13} poços, cujos perfis elétricos foram analisados, têm suas localizações indicadas no mapa da figura 1. Em geral, esses perfis correspondem ao perfil de eletroindução, que consiste em uma curva de indução, uma curva do normal curto de 16 pol $(40,6 \mathrm{~cm})$ de separação e uma curva do potencial espontâneo. Para alguns dos poços foram executadas também, adicionalmente, microperfis de resistividade (micronormal de 2 pol, microlateral de $1 \times 1$ pol e calibre). Dois poços (Biritinga CERB-VII e CERB-VIII) dispõem apenas dos microperfis.

Os perfis elétricos foram utilizados pelos procedimentos convencionais (Lynch 1962) em: i) determinação dos limites das camadas permeáveis e de suas resistividades verdadeiras $\left(R_{\mathrm{V}}\right)$ a partir das curvas de indução; ii) determinação da resistividade da água presente nos vários níveis aqüíferos $\left(R_{\text {ea }}\right)$ a partir da curva do potencial espontâneo; e iii) estimativa de valores de porosidade efetiva $(\phi)$ das camadas de arenitos usando uma expressão particular da Lei de Archie.

Os valores de $R_{\mathrm{V}}$ foram determinados diretamente do perfil de indução. Como as espessuras das camadas de arenitos são normalmente grandes comparadas com a dimensão da sonda e, em função do elevado contraste de resistividade que apresentam com as rochas adjacentes, não se fez necessária nenhuma correção nos valores lidos nos perfis (Lynch 1962). A figura 2 mostra os perfis litológicos dos poços Pataíba CERB-II e Biritinga CERB-V, construídos com base nos perfis elétricos e na amostragem de calha obtida durante a perfuração dos poços.

Os valores dę $R_{\text {ea }}$ foram estimados a partir da deflexão da curva do potencial espontâneo com respeito à linha de base dos folhelhos, supondo que essa deflexão corresponde integralmente ao potencial eletroquímico, usando a expressão (Schlumberger 1972):

$$
P E=-K \log \frac{R_{\mathrm{f} 1}}{R_{\text {ea }}}
$$

na qual $P E$ é a deflexão máxima do potencial espontâneo; $K$, uma constante (igual a 71 à temperatura de $25^{\circ} \mathrm{C}$ ); $R_{\mathrm{fl}}$, a resistividade do filtrado na lama, normalmente fornecida nos perfis; e $R_{\text {ea }}$ a resistividade equivalente da água em termos daquela de uma solução de cloreto de sódio.

De posse dos valores de $R_{\mathrm{V}}$ e $R_{\text {ea }}$ foi possível fazer estimativas de porosidades dos níveis de arenitos usando a Lei de Archie (Archie 1942) dada por:

$$
F=a \cdot \theta^{-\mathrm{m}}
$$

em que $F$ é o fator de resistividade da formação (dado como $F=R_{\mathrm{V}} / R_{\text {ea }}$ ); e $a$ e $m$ são parâmetros que dependem da forma e do arranjo dos grãos na arquitetura do meio poroso. Para arenitos limpos e pouco cimentados pode-se adotar $a=0,62$ e $m=2,15$ (Schlumberger 1972). Na tabela 1 acham-se resumidos, para os poços com informações disponíveis suficientes, os dados petrofísicos estimados para os mais importantes níveis aqüíferos atravessados pelos poços.

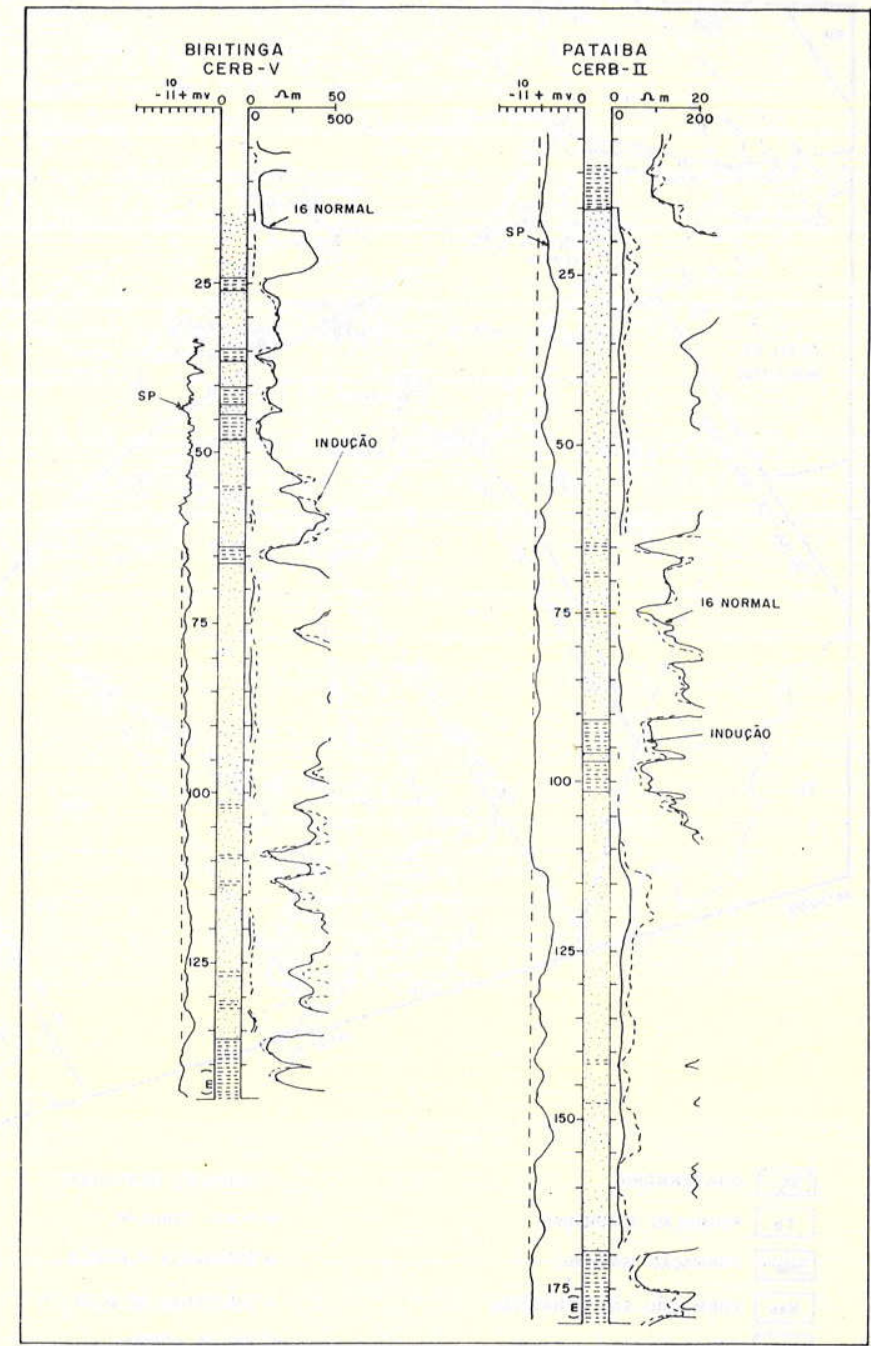

Figura 2 - Perfis elétricos típicos de poços perfurados sobre os grupos Ilhas e Massacará na região de Biritinga-Pataiba

Tabela 1 - Valores de resistividade $\left(\mathrm{R}_{\mathrm{V}}\right)$, resistividade da água ( $\mathrm{R}_{\mathrm{ea}}$ ) e porosidade $(\phi)$ das camadas de arenitos atra-

\begin{tabular}{|c|c|c|c|c|}
\hline Poşo & $\begin{array}{l}\text { Intervalo de profundidade } \\
(\mathrm{m})\end{array}$ & $\begin{array}{l}R \mathrm{v} \\
(\Omega \mathrm{m})\end{array}$ & $\begin{array}{l}R \mathrm{ea} \\
(\Omega \mathrm{m})\end{array}$ & $\left.\begin{array}{r}\phi \\
\mid\left(\mathrm{n}_{0}\right)\end{array}\right)$ \\
\hline $\mathrm{Bi}-1-\mathrm{BA}$ & $\begin{array}{r}61-107 \\
135-184 \\
250-265 \\
\end{array}$ & $\begin{array}{l}75 \\
40 \\
22 \\
\end{array}$ & $\begin{array}{l}6,7 \\
9,9 \\
9,0\end{array}$ & $\begin{array}{l}26 \\
42 \\
52\end{array}$ \\
\hline $\begin{array}{l}\text { Biritinga } \\
\text { (CERB-VI) }\end{array}$ & $\begin{array}{c}14-67 \\
130-164 \\
\end{array}$ & $\begin{array}{l}80 \\
50 \\
\end{array}$ & $\begin{array}{l}8,2 \\
7,6 \\
\end{array}$ & $\begin{array}{l}27 \\
33 \\
\end{array}$ \\
\hline $\begin{array}{l}\text { Biritinga } \\
\text { (CERB-IV) }\end{array}$ & $\begin{array}{c}58-85 \\
90-112 \\
130-152 \\
177-198 \\
\end{array}$ & $\begin{array}{r}110 \\
50 \\
50 \\
45 \\
\end{array}$ & $\begin{array}{l}9,9 \\
7,6 \\
7,6 \\
5,4\end{array}$ & $\begin{array}{l}26 \\
33 \\
33 \\
29 \\
\end{array}$ \\
\hline $\begin{array}{l}\text { Biritinga } \\
\text { (CERB-V) }\end{array}$ & $\begin{array}{c}0-33 \\
58-146 \\
153-172\end{array}$ & $\begin{array}{l}50 \\
90 \\
80\end{array}$ & $\begin{array}{l}8,7 \\
8,1 \\
6,7\end{array}$ & $\begin{array}{l}35 \\
26 \\
25\end{array}$ \\
\hline $\begin{array}{l}\text { Biritinga } \\
\text { CERB-IX) }\end{array}$ & $\begin{array}{c}50-88 \\
110-219 \\
\end{array}$ & $\begin{array}{r}70 \\
100 \\
\end{array}$ & $\begin{array}{l}8,4 \\
7,6 \\
\end{array}$ & $\begin{array}{l}29 \\
24\end{array}$ \\
\hline $\begin{array}{l}\text { Biritinga } \\
\text { (CERB-II) }\end{array}$ & $\begin{array}{c}34-53 \\
58-97 \\
110.125 \\
150-160 \\
\end{array}$ & $\begin{array}{r}100 \\
125 \\
35 \\
50 \\
\end{array}$ & $\begin{array}{l}6,5 \\
5,8 \\
4,8 \\
3,5\end{array}$ & $\begin{array}{l}22 \\
19 \\
32 \\
28 \\
\end{array}$ \\
\hline $\begin{array}{l}\text { Pataiba } \\
\text { (CERB-II) }\end{array}$ & $\begin{array}{r}23-69 \\
118-173\end{array}$ & $\begin{array}{r}60 \\
100\end{array}$ & $\begin{array}{l}4,0 \\
4,7\end{array}$ & $\begin{array}{l}23 \\
19\end{array}$ \\
\hline
\end{tabular}
vessadas pelos poços de área de Biritinga-Pataíba 
Verifica-se desses dados que, em geral, os valores de $R_{\text {ea }}$ decrescem com a profundidade, o que significa que há um aumento progressivo da salinidade da água com a profundidade.

$O$ perfil do potencial espontâneo do poço Bi-1-BA indica

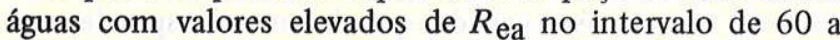
$265 \mathrm{~m}$ e registra uma passagem para água salobra na profundidade de $365 \mathrm{~m}$. Do mesmo modo, os poços Biritinga CERB-IV e Biritinga CERB-II registram essa passagem nas profundidades de 177 e $125 \mathrm{~m}$, respectivamente. Para os poços Pi-1-BA e Pataíba CERB-II as estimativas de $R_{\text {ea }}$ indicam que todos os corpos arenosos atravessados pelos furos fornecem águas salobras, provavelmente com mais de $2.000 \mathrm{ppm}$ equivalentes em $\mathrm{NaCl}$ de sais dissolvidos. Os valores de resistividade das águas amostradas em dois desses poços, constantes da tabela 2 , são maiores que os estimados usando a equação (1). Isto se deve ao fato de o emprego da equação (1) requerer que tanto a água do aqüífero como a usada no preparo da lama sejam soluções basicamente constituídas de cloreto de sódio (Goundouin et al. 1957). Todavia, os dados da tabela 2 indicam que as águas contêm, além de $\mathrm{NaCl}$, quantidades apreciáveis de $\mathrm{Ca}$ e $\mathrm{Mg}$. $\mathrm{O}$ efeito desses íons sobre o potencial espontâneo é tal que $R_{\text {ea }}$ interpretado usando a equação (1) resulta na indicação de uma água mais salina do que ela realmente é (Alger 1966, Lima \& Ribeiro 1982). Infelizmente, a quantidade de dados obtidos neste trabalho não é suficiente para construir uma relação empírita entre a resistividade estimada do $P E\left(R_{\mathrm{ea}}\right)$ e $R_{\mathrm{a}}$ efetivamente medida, válida para a região estudada.

Os dados de porosidade estimados usando a equação (2) indicam valores usuais para arenitos de granulação fina, exceto quando os mesmos são muito argilosos, casos em que esses valores se tornam muito elevados. Tal fato resulta da contribuição da argila no processo de condução da corrente elétrica, que não é considerada na expressão da Lei de Archie (equação 2). Esse efeito tem sido observado por vários autores (Patnode \& Wyllie 1950, De Witte 1957), Worthington 1977, entre outros). Os valores anômalos assim obtidos podem, todavia, ser utilizados de maneira qualitativa para estimar a argilosidade dos arenitos.

Além dessas utilizações, os perfis elétricos foram analisados no sentido de identificar níveis litológicos que pudessem ser usados como marcos de correlação litoestratigráfica entre os diversos poços. Esta correlação, ampliada com os resultados das sondagens elétricas e das análises químicas das águas, será discutida posteriormente com maiores detalhes.

\section{INTERPRETAÇÃO QUANTITATIVA DAS SONDAGENS}

ELÉTRICAS Com o objetivo de ampliar as informações sobre a distribuição vertical de arenitos e folhelhos nos grupos Ilhas e Massacará, em termos de suas espessuras e resistividades, foram executadas na área 28 sondagens elétricas verticais utilizando a configuração de Schlumberger, até uma separação máxima entre os eletrodos de corrente de $2 \mathrm{~km}$. Dez sondagens foram centradas em poços e serviram para calibrar a interpretação quantitativa e reduzir os problemas de equivalência e supressão, característicos do método elétrico. Tendo em vista os propósitos do presente trabalho, serão apresentadas 22 curvas de sondagens consideradas representativas da área e suficientes para justificar as conclusões atingidas.

A instrumentação utilizada no campo consistiu em um sistema transmissor projetado e construído no PPPG/UFBa e um sistema receptor que constitui o potenciômetro do equipamento Terrameter modelo 5310 da Atlas Copco ABEM. O sistema transmissor com potência de $1 \mathrm{~kW}$ gera uma corrente alternada na freqüência de $4 \mathrm{~Hz}$ e sua tensão de saída pode variar de 0 a $840 \mathrm{~V}$. O receptor mede valores de resistência $(\triangle V / I)$ com precisão de $3 \%$ para valores acima de $0,03 \Omega$ e de $10 \%$ até valores de ordem de $0,003 \Omega$.

Tabela 2 - Dados das análises físico-químicas das amostras de água do aqüifero freático da região de Biritinga-Pataíba

\begin{tabular}{l|c|r|r|r|r|r|r|r|r|r}
\hline \multicolumn{1}{c|}{ POÇO } & $\begin{array}{c}\text { Profundidade } \\
(\mathrm{m})\end{array}$ & $\mathrm{pH}$ & $\mathrm{p}_{a}(\Omega \mathrm{m})$ & $\mathrm{HCO}_{3}^{-}$ & $\mathrm{Ca}^{++}$ & $\mathrm{Mg}^{++}$ & $\mathrm{Na}^{+}$ & $\mathrm{K}^{+}$ & $\mathrm{Cl}^{-}$ & $\mathrm{SO}_{4}^{--}$ \\
\hline 01. Cacimba & 5,5 & 7,9 & 0,6 & 338,6 & 40,5 & 81,3 & $1.300,0$ & 235,0 & $4.260,0$ & 40,0 \\
02. Cacimba & 4,0 & 7,8 & 4,3 & 75,3 & 19,8 & 29,2 & 154,0 & 35,0 & 468,6 & 84,5 \\
03. Fazenda Barreiro & 5,2 & 8,7 & 1,5 & 88,4 & 88,5 & 87,8 & 477,0 & 30,0 & $1.597,5$ & 230,0 \\
04. Fonte Inhambupe & 1,5 & 8,0 & 5,7 & 70,4 & 15,0 & 12,4 & 84,0 & 28,0 & 158,0 & 42,3 \\
05. Fonte Barreiro & 2,0 & 6,9 & 15,5 & 38,6 & 5,0 & 8,5 & 44,0 & 6,0 & 110,1 & 15,5 \\
06. Cacimba & 8,0 & 6,8 & 8,7 & 72,0 & 2,5 & 2,5 & 111,6 & 6,0 & 134,9 & 31,7 \\
07. Cacimba & 6,6 & 8,1 & 4,6 & 157,4 & 28,5 & 28,7 & 151,5 & 24,0 & 291,1 & 49,7 \\
08. Fonte Bebedor & 0,8 & 6,0 & 20,6 & 13,6 & 3,5 & 5,4 & 31,5 & 6,5 & 294,7 & 4,0 \\
09. Cacimba & 8,0 & 7,0 & 17,5 & 42,2 & 5,5 & 6,0 & 41,5 & 4,0 & 298,2 & 10,3 \\
10. Fonte Bambori & 1,5 & 6,0 & 18,3 & $16,2$. & 5,5 & 8,1 & 31,0 & 6,0 & 294,7 & 1,7 \\
11. Cacimba Salgado & 3,0 & 8,2 & 8,8 & 83,8 & 8,5 & 3,1 & 105,0 & 1,5 & 316,6 & 17,7 \\
12. Cacimba Vagem & 3,8 & 8,9 & 1,7 & 179,9 & 29,0 & 17,3 & 439,0 & 7,0 & 916,0 & 116,0 \\
13. Cacimba Paracatu & 1,8 & 8,7 & 8,6 & 191,1 & 5,5 & 2,2 & 130,5 & 0,1 & 316,0 & 15,5 \\
14. Fonte Cangorra & 2,0 & 6,8 & 25,0 & 41,9 & 9,5 & 5,1 & 25,0 & 0,1 & 36,6 & 1,7 \\
15. Cacimba Pataíba & 5,0 & 8,4 & 6,2 & 90,8 & 5,0 & 1,0 & 155,0 & 0,1 & 198,8 & 23,2 \\
\hline
\end{tabular}


As curvas de sondagens foram interpretadas com modelos de quatro a oito camadas horizontais, que refletem a variabilidade litológica e estrutural da área. $\mathrm{Na}$ interpretação das sondagens, foi adotado o procedimento de superposição total pela derivação de curvas teóricas do computador VAX 11/780 do PPPG/UFBa. Foi utilizado para isso o método do filtro linear (Ghosh 1971), de acordo com o algoritmo desenvolvido por Anderson (1979). Como ponto de partida para a computação, foram usados os modelos aproximados obtidos com o método do ponto auxiliar (Zohdy 1965) e os ajustes foram feitos por procedimentos de tentativa.

Sondagens Elétricas sobre o Grupo Ilhas Na figura 3 estão representadas curvas típicas de sondagens executadas sobre o bloco estrutural limitado pelas falhas de Biritinga e Norte Pau do Oco (Fig. 1), sendo uma delas (SE-04) paramétrica ao poço CERB-VIII. Esta foi interpretada usando um modelo de cinco camadas. A primeira corresponde ao solo arenoso de alta resistividade e de pequena espessura. Seguem-se duas camadas com 80 e $45 \Omega \mathrm{m}$ de resistividade até $29 \mathrm{~m}$ de profundidade que vêm associadas a arenitos argilosos conforme o perfil litológico do furo CERB-VIII. Abaixo dessa camada tem-se um intervalo condutor de $16 \Omega \mathrm{m}$ de resistividade, que corresponde a uma seqüência dominantemente constituída de folhelhos. A camada de $90 \Omega \mathrm{m}$, que ocorre abaixo de $115 \mathrm{~m}$ de profundidade, representa os espessos arenitos descritos como menos argilosos que os do topo da seção geoelétrica. As sondagens SE-26 e SE-27 também foram interpretadas com modelos de cinco camadas e a sucessão litológica envolve, abaixo da camada de solo, uma seqüência de níveis condutores até

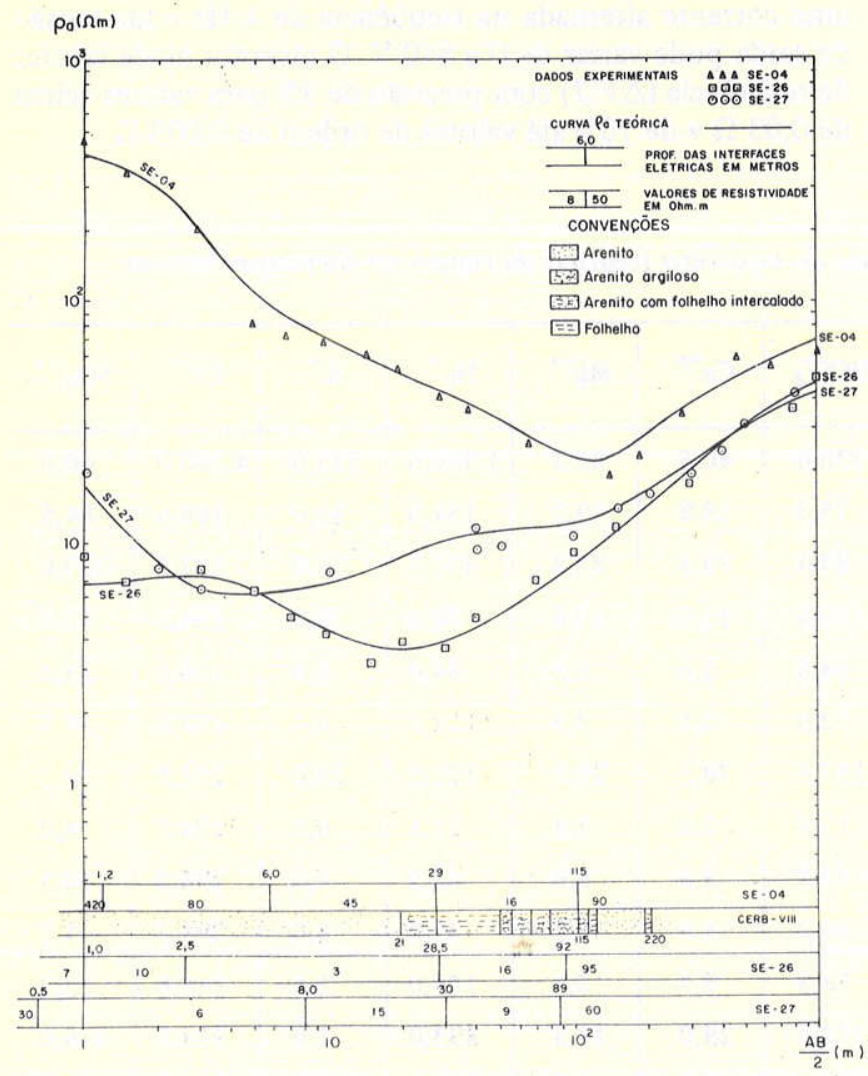

Figura 3 - Curvas de sondagens elétricas realizadas sobre o bloco limitado pelas falhas de Biritinga e Norte Pau do Oco (SE-04, SE-26 e SE-27) profundidades de 92 e $89 \mathrm{~m}$, respectivamente, em SE-26 e SE-27, interpretada como pacotes de folhelhos, os quais podem conter pequenos níveis de siltitos e arenitos intercalados, similares àquele do furo CERB-VIII. Sob os folhelhos, desenvolvem-se níveis espessos e mais resistivos com 95 e $60 \Omega \mathrm{m}$ de resistividade, que devem corresponder aos arenitos espessos da base da seqüência, como em SE-04.

A figura 4 mostra curvas típicas das sondagens realizadas no bloco limitado pelas falhas Norte Pau do Oco e Pau do Oco (Fig. 1). As curvas das sondagens SE-05, SE-07 e SE-09 foram interpretadas com modelos de cinco camadas. SE-05 é caracterizada, até $35 \mathrm{~m}$ de profundidade, por um conjunto de camadas elétricas cujas resistividades diminuem com a profundidade, provavelmente como conseqüência de um aumento na quantidade de argila nos arenitos, até passar aos folhelhos de $15 \Omega \mathrm{m}$ de resistividade, conforme perfil do poço CERB-V. A sondagem SE-07 mostra uma espessa seqüência de condutores que se estende até $104 \mathrm{~m}$ de profundidade e que corresponde a uma associação de folhelhos puros, folhelhos arenosos e folhelhos conglomeráticos, de acordo com a coluna litológica do poço CERB-IX. Abaixo dos condutores desenvolvem-se, nas duas curvas, arenitos espessos caracterizados pela resistividade de $120 \Omega \mathrm{m}$. Em SE-09, abaixo do solo ocorre uma camada de $20 \Omega \mathrm{m}$ de resistividade, que é interpretada como constituída dominantemente por folhelhos. De 13 a $155 \mathrm{~m}$ tem-se uma camada de $120 \Omega \mathrm{m}$ de resistividade, que certamente representa um espesso pacote de arenitos limpos. $\mathrm{O}$ ramo terminal descendente da curva revela a influência de um substrato condutor constituído predominantemente por litologias do tipo folhelho.

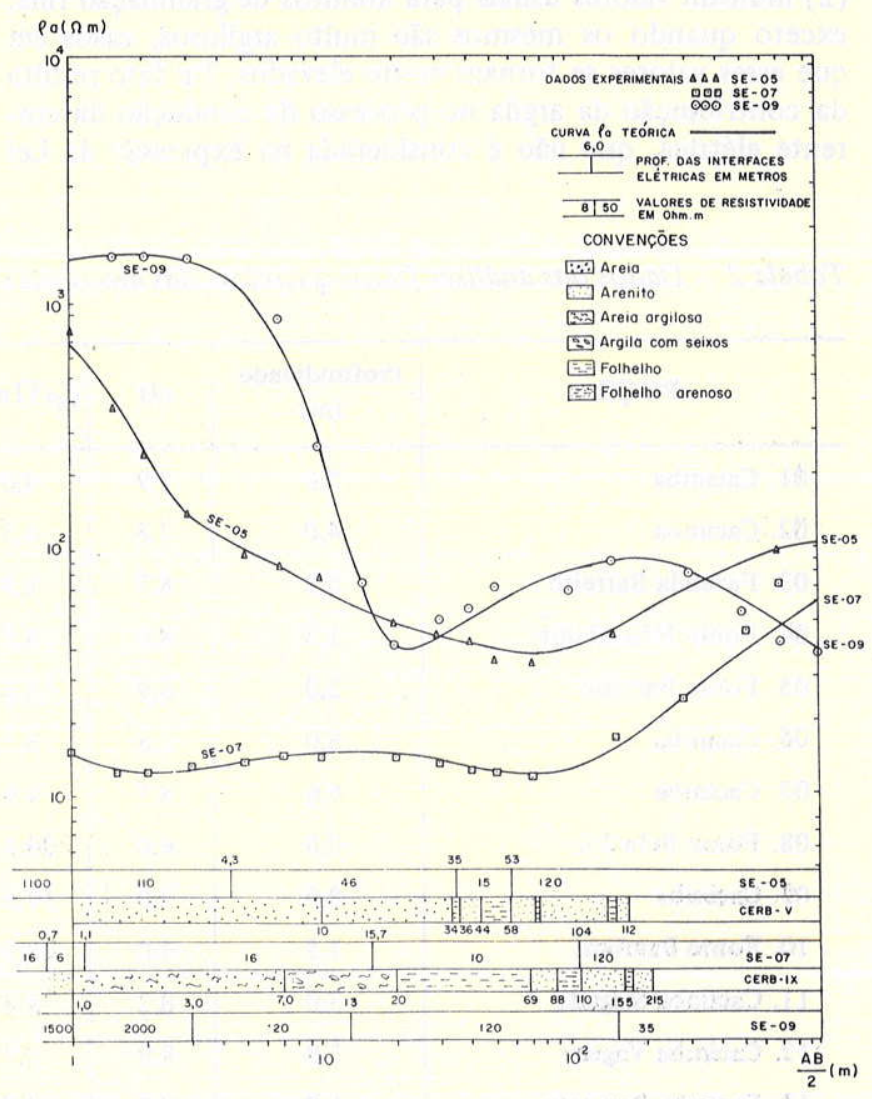

Figura 4 - Curvas de sondagens elétricas realizadas sobre o bloco limitado pelas falhas Norte Pau do Oco e Pau do Oco (SE-05, SE-07 e SE-09) 
$\mathrm{Na}$ figura 5, têm-se as curvas das sondagens SE-10 e SE-11, obtidas sobre o bloco limitado pelas falhas Pau do Oco e Fazenda Caatinga (Fig. 1). A curva SE-10 mostra, abaixo do solo, um nível condutor com $12 \mathrm{~m}$ de espessura e $20 \Omega \mathrm{m}$ de resistividade. Sob esse nível, ocorrem duas camadas resistivas (150 e $200 \Omega \mathrm{m}$ ) limitadas pelas profundidades de 15 e $153 \mathrm{~m}$, que estão separadas por um intervalo condutor de $20 \Omega \mathrm{m}$ de resistividade. A parte final descendente da curva é representada por uma camada de $50 \Omega \mathrm{m}$. Em SE-11 ocorre uma sucessão de camadas resistivas até $30 \mathrm{~m}$ de profundidade. Em seguida, revela-se um intervalo condutor de $25 \Omega \mathrm{m}$ de resistividade e $30 \mathrm{~m}$ de espessura, que se superpõe a uma camada espessa e resistiva $(62 \mathrm{~m}$ e $210 \Omega \mathrm{m})$. A parte final da curva vem associada com um substrato de $62 \Omega \mathrm{m}$ de resistividade. Os intervalos condutores nessas sondagens representam camadas constituídas com predomínio de folhelhos enquanto os níveis resistivos mais elevados ( $>100 \Omega \mathrm{m})$ vêm associados a pacotes de arenitos limpos. As camadas basais nos ramos terminais das curvas, com valores intermediários de resistividade, são interpretadas como arenitos mais argilosos ou contendo intercalações de leitos de folhelhos ou de siltitos.

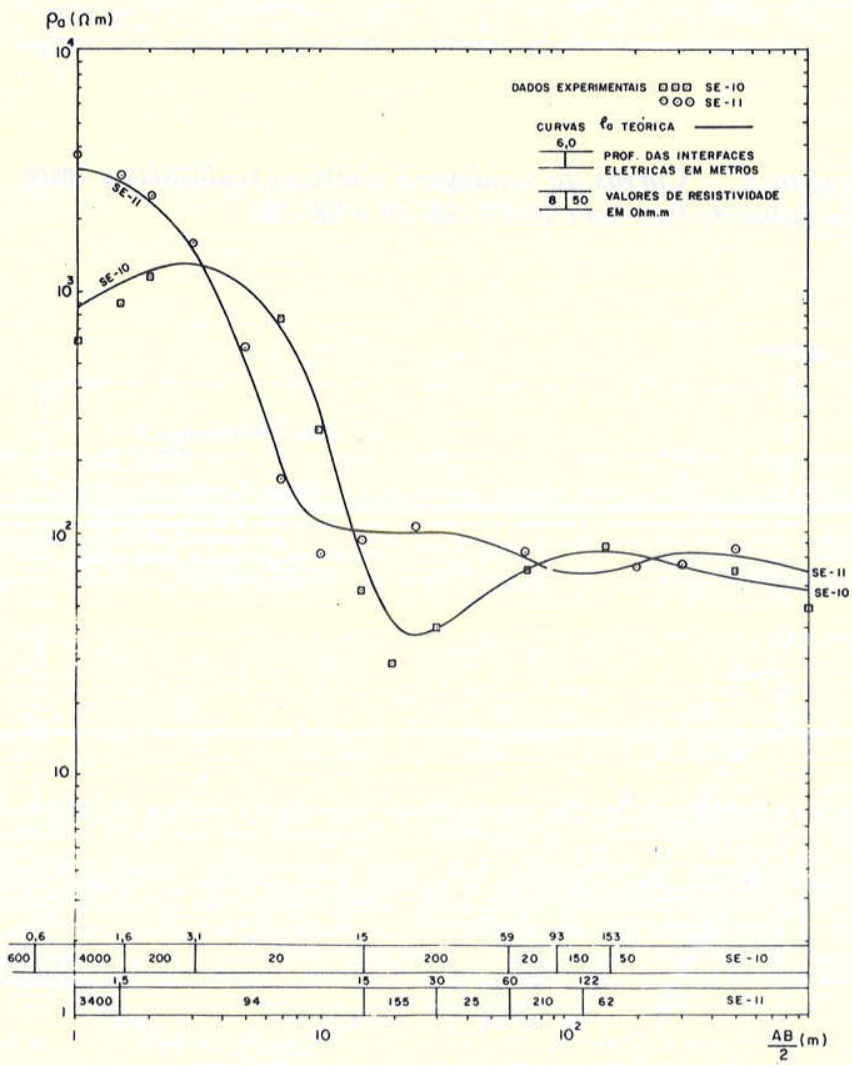

Figura 5 - Curvas de sondagens elétricas realizadas sobre o bloco limitado pelas falhas Pau do Oco e Fazenda Caatinga (SE-10 e SE-11)

$\mathrm{Na}$ figura 6 estão representadas as curvas de sondagens cujos centros foram localizados no bloco limitado pelas falhas das fazendas Caatinga e Olhos D'Água (Fig. 1). A sondagem SE-12 indica, sob a camada de solo argiloso, a existência de um nível arenoso representado pela camada geoelétrica de $80 \Omega \mathrm{m}$ de resistividade, que se estende até $35 \mathrm{~m}$ de profundidade. Segue-se uma seqüência dominada por folhelhos conforme se infere de sua resistividade de $14 \Omega \mathrm{m}$. Abaixo de $112 \mathrm{~m}$, a resistividade é típica de pacotes de arenitos, os quais são muito espessos, como atestam a extensões dos ramos terminais ascendentes das curvas. As curvas de SE-23, SE-24 e SE-25 mostram, em função dos valores das resistividades das camadas situadas acima de $100 \mathrm{~m}$ de profundidade, que esta seção é constituída por unidades litológicas argilosas do tipo folhelho, que contêm intercalados leitos de resistividade intermediária com cerca de $25 \mathrm{~m}$ de espessura. Os ramos terminais ascendentes dessas curvas, assim como a de SE-12, indicam a presença de espessos pacotes de arenitos abaixo dos $100 \mathrm{~m}$ de profundidade.

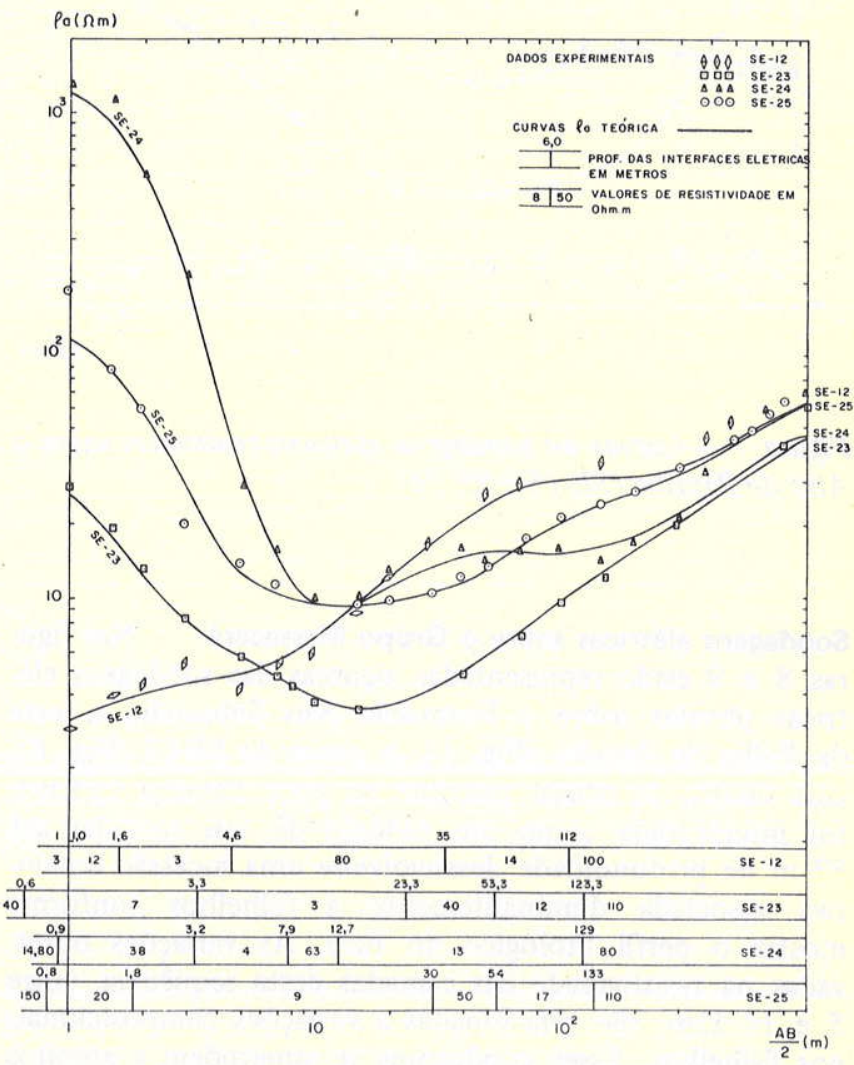

Figura 6 - Curvas de sondagens elétricas realizadas sobre o bloco limitado pelas falhas da Fazenda Caatinga e Olhos D'Água (SE-12, SE-23, SE-24 e SE-25)

A figura 7 apresenta as curvas das sondagens executadas sobre o Alto de Pataíba, respectivamente as sondagens SE-15 e SE-28 (Fig. 1). Os modelos interpretados exibem um padrão de distribuição vertical de resistividade similar ao da figura 6 , onde o pacote litológico do topo, entre a profundidade de $45 \mathrm{~m}$ em SE-28 e $140 \mathrm{~m}$ em SE-15, é dominado por folhelhos condutores contendo níveis locais mais resistivos, provavelmente constituídos por arenitos argilosos em função do valor de $60 \Omega \mathrm{m}$ de suas resistividades. Os ramos terminais ascendentes das curvas são associados a espessas camadas de arenitos. 


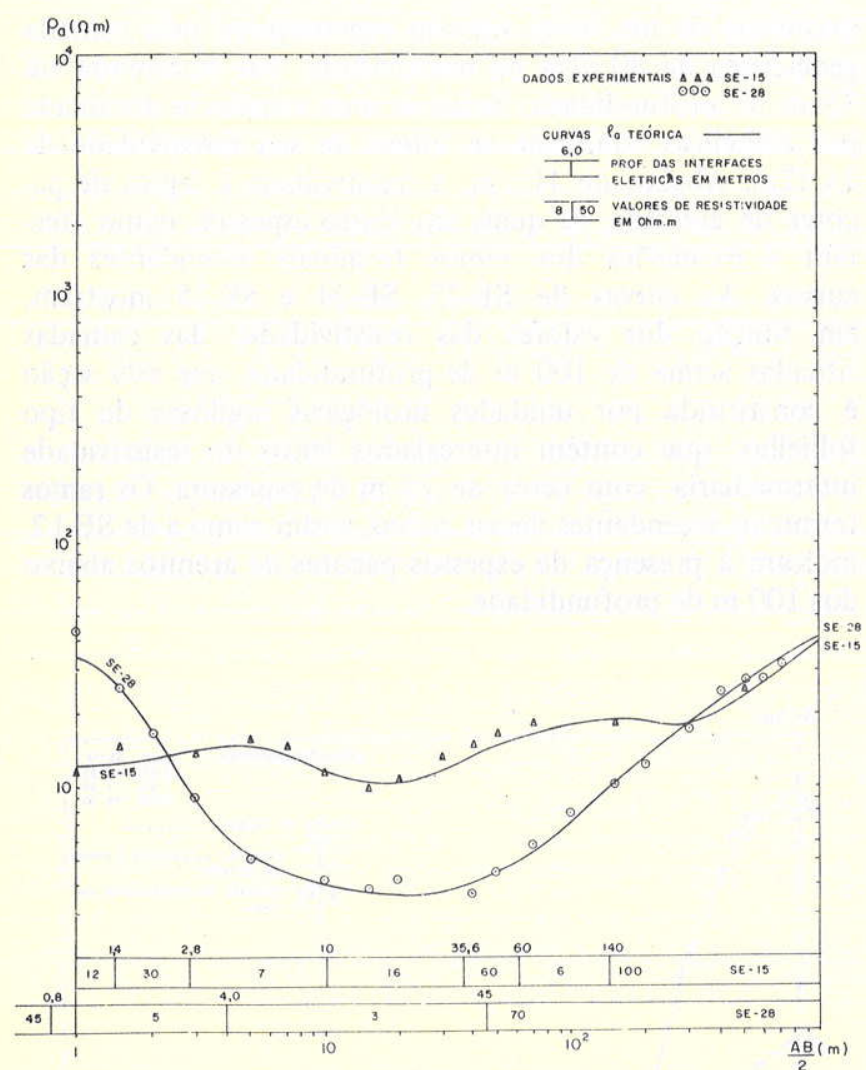

Figura 7 - Curvas de sondagens elétricas realizadas sobre 0 Alto de Pataiba (SE-15 e SE-28)

Sondagens elétricas sobre o Grupo Massacará Nas figuras 8 e 9 estão representadas algumas das sondagens elétricas obtidas sobre a Formação São Sebastião, a leste da Falha de Pataíba (Fig. 1). A curva de SE-13 (Fig. 8), cujo centro se situou próximo ao poço Pataíba CERB-I, foi interpretada como um modelo de seis camadas até $87 \mathrm{~m}$ de profundidade desenvolve-se uma sucessão condutiva associada dominantemente a folhelhos conforme mostra o perfil litológico do furo. As variações observadas na resistividade das camadas desta seqüência, entre 5 e $14 \Omega \mathrm{m}$, são relacionadas a variações composicionais nos folhelhos. Esses condutores se superpõem a arenitos basais espessos com resistividade de $54 \Omega \mathrm{m}$. As curvas de SE-19 e SE-20 apresentam padrões caracterizados por intercalações de folhelhos (1 a $18 \Omega \mathrm{m}$ ) e arenitos (32 a $40 \Omega \mathrm{m}$ ) na parte da seqüência situada acima das profundidades de 84 e $99 \mathrm{~m}$, respectivamente. Estes pacotes superiores repousam sobre camadas espessas ligeiramente mais resistivas $(50$ a $60 \Omega \mathrm{m}$ ) representadas pelos ramos terminais ascendentes das curvas.

A figura 9 ilustra um segundo conjunto de curvas obtidas sobre a Formação São Sebastião, que mostra padrões uniformes na distribuição das resistividades em subsuperfície, apenas com pequenas diferenças nas posições dos máximos e mínimos das curvas relacionadas a variações de espessura das várias camadas. Todas as curvas indicam intercalações de folhelhos ( 8 a $19 \Omega \mathrm{m}$ ) e arenitos (32 a $35 \Omega \mathrm{m}$ ) até profundidades da ordem de $100 \mathrm{~m}$, as quais se superpõem a pacotes mais espessos de arenitos com resistividades no intervalo de 43 a $60 \Omega \mathrm{m}$.

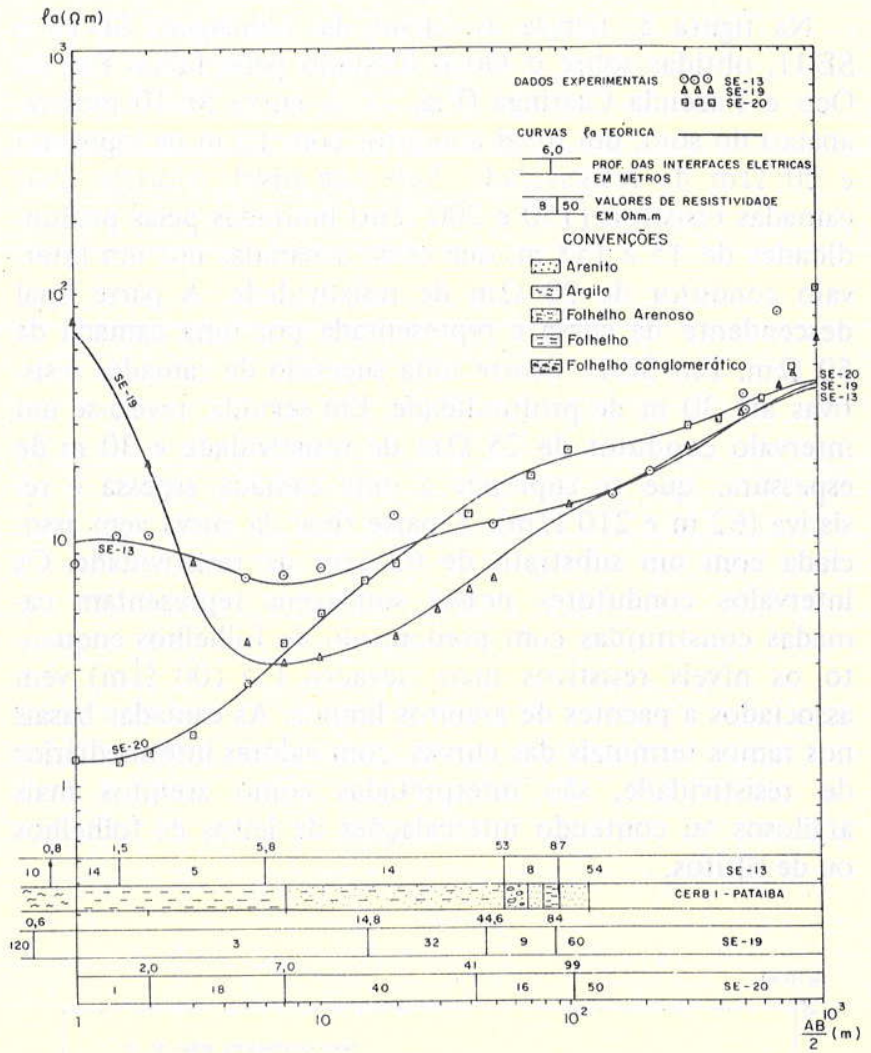

Figura 8 - Curvas de sondagens elétricas realizadas a leste da Falha de Pataiba (SE-13, SE-19 e SE-20)

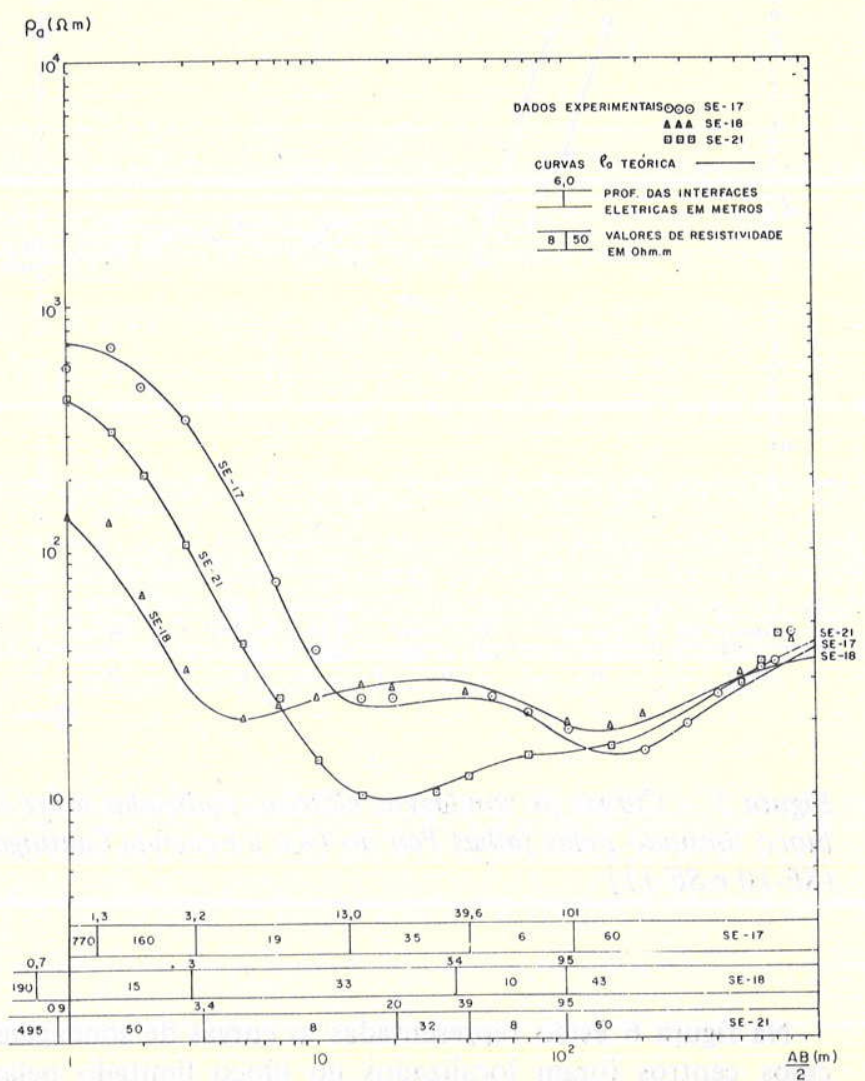

Figura 9 - Curvas de sondagens elétricas realizadas a leste da Falha de Pataiba (SE-17, SE-18 e SE-21) 
CARACTERISTICAS QUIIMICAS DAS ÁGUAS SUBTER-

RÂNEAS Como suporte aos estudos geofísicos, foram realizadas análises físico-químicas de amostras de água subterrânea, tanto do aqüifero freático, amostrado em poços rasos de uso doméstico, como do sistema confinado, amostrado nos poços tubulares em funcionamento na região. Os pontos de amostragem de água acham-se indicados na figura 1 e os resultados das análises estão resumidos nas tabelas 2 e 3 .

Os dados da tabela 2 indicam que a água do aqüífero freático só é utilizável para consumo humano ao longo da área aluvionar do Rio Inhambupe, na qual os valores de $R_{\mathrm{a}}$ a $25^{\circ} \mathrm{C}$ são superiores a $5 \Omega \mathrm{m}$, valor de resistividade equivalente a de uma solução com $1.000 \mathrm{ppm}$ de $\mathrm{NaCl}$ dissolvido. Fora dessa região, a água do sistema se apresenta normalmente salinizada com mais de $1.000 \mathrm{ppm}$ equivalentes de $\mathrm{NaCl}$ e com os teores de $\mathrm{Na}^{+}, \mathrm{Cl}^{-}, \mathrm{Ca}^{+2}$ e $\mathrm{Mg}^{+2}$ em geral, bem acima dos valores médios adotados para água potável. Por isso, nos poços tubulares em exploração, localizados nas proximidades de Biritinga, geralmente o aqüífero freático tem sido isolado por meio de um colar de cimentação (CERB 1975, 1981, 1983). O principal fator responsável pela salinização da água do lençol freático é a intensa evaporação da água do solo e do próprio aqüífero; com a conseqüente concentração de sais nas águas. Em vários locais em superfície pode-se observar, nos períodos secos, até a precipitação de cristais de $\mathrm{NaCl}$ no solo superficial. Nos períodos de chuva, esse sal é carreado ao aqüífero e contrubui para o aumento da salinidade da água.
Esse efeito da evaporação é minimizado nas áreas aluvionares em conseqüência de uma maior drenagem superficial e da proteção exercida pela vegetação mais exuberante, que se desenvolve nessas regiões.

$\mathrm{Na}$ tabela 3 têm-se os dados das análises das águas dos poços tubulares, que exploram o sistema aquífero confinado. As amostras analisadas constituem misturas de águas de qualidades ligeiramente diferentes, que estão contidas nos diversos corpos de arenitos atravessados pelos poços. Os dados da tabela 3 indicam que a maioria das águas possuem resistividades superiores a $5 \Omega \mathrm{m}$, com exceção dos poços Embasa-06, Fazenda Lagoa, Caçuá e Pataíba CERB-I, que produzem águas salinizadas. Os três últimos poços têm usos domésticos restritos, tais como na lavagem de roupas e no asseio pessoal. O poço Embasa-06, todavia, faz parte da bateria que abastece a cidade de Serrinha e sua água é admitida e diluída na mistura com águas mais potáveis dos outros poços da bateria. Também os teores de ânions e cátions dissolvidos nessas águas estão dentro dos padrões normais de águas potáveis, com exceção das dos quatro poços acima referidos, nos quais os teores de $\mathrm{Na}^{+} \mathrm{e} \mathrm{Cl}^{-}$estão acima dos valores máximos estabelecidos (Walton 1970). Além dos nove poços dados na tabela 3, foram abandonados por produzirem águas muito salinizadas (A.M. Guerra, da CERB, comunicação verbal) os poços Embasa-02, Embasa-03 e Embasa-05 localizados próximo a Biritinga e o poço Pataíba CERB-II com $200 \mathrm{~m}$ de profundidade e resistividade equivalente da água entre 4,3 e $5,1 \Omega \mathrm{m}$ (Tab. 1).

Tabela 3 - Dados das análises físico-quimicas das amostras de água do sistema aqüifero confinado da região de Biritinga-Pataiba

\begin{tabular}{l|c|c|c|c|c|c|c|c|c|c}
\hline \multicolumn{1}{c|}{ POÇO } & $\begin{array}{c}\text { Profundidade } \\
(\mathrm{m})\end{array}$ & $\mathrm{pH}$ & $\mathrm{p}_{a}(\Omega \mathrm{m})$ & $\mathrm{HCO}_{3}^{-}$ & $\mathrm{Ca}^{++}$ & $\mathrm{Mg}^{++}$ & $\mathrm{Na}^{+}$ & $\mathrm{K}^{+}$ & $\mathrm{Cl}^{-}$ & $\mathrm{SO}_{4}^{--}$ \\
\hline Embasa 04 & - & 7,8 & 8,2 & 8,35 & 29,5 & 17,0 & 65,0 & 0,5 & 155,5 & 13,5 \\
Fazenda Lagoa & 72 & 7,5 & 4,3 & 97,1 & 36,0 & 40,5 & 133,0 & 11,5 & 355,0 & 46,4 \\
CERB-III - Embasa 01 & 200 & 8,5 & 10,5 & 110,7 & 2,0 & 2,9 & 98,0 & 0,1 & 77,4 & 20,3 \\
Embasa 06 & - & 8,4 & 3,7 & 100,8 & 25,0 & 22,7 & 16,0 & 0,1 & 479,3 & 23,2 \\
CERB-II - Embasa 08 & 102 & 6,6 & 19,4 & 20,6 & 5,0 & 8,4 & 32,5 & 6,0 & 81 & 5,9 \\
CERB-V - Embasa 11 & 166 & 6,5 & 24,1 & 23,2 & 5,0 & 6,4 & 24,0 & 5,0 & 53,3 & 4,0 \\
CERB-IV - Embasa 10 & 202 & 6,8 & 16,6 & 43,7 & 4,5 & 7,5 & 38,0 & 1,0 & 75,3 & 10,3 \\
Cacica & 160 & 8,3 & 4,1 & 88,7 & 17,5 & 25,3 & 171,0 & 9,5 & 390,5 & 42,3 \\
Pataíba CERB-1 & 115 & 6,0 & 3,2 & 15,1 & 25,5 & 74,7 & 134,0 & 28,0 & 674,5 & 0,0 \\
\hline
\end{tabular}


ESTRUTURA DOS AQÜIFEROS E A SALINIZAÇÃO DAS ÁGUAS A correlação litoestratigráfica estabelecida a partir da análise dos perfis elétricos dos poços e das seções geoelétricas derivadas das sondagens de resistividade, conforme apresentada na figura 10, mostra que a estrutura do sistema aqüífero dos grupos Illhas e Massacará na região estudada compreende um conjunto de blocos falhados em altos e baixos estruturais. Dessa estrutura, já eram reconhecidos o Alto de Biritinga definido por Araújo (1971) e o Alto de Pataíba definido como Horst de Pataíba no mapa geológico da região, elaborado pela Petrobrás. Os demais blocos foram delineados neste trabalho e envolvem o prolongamento direcional de algumas das falhas, conforme se infere da figura 1.

Nos blocos estruturalmente mais elevados como o Alto de Biritinga, o Alto Pau do Oco e o Alto de Pataíba, o sistema aqǘfero corresponde, em grande parte, às unidades A e B do Grupo Ilhas, compostas de arenitos argilosos e folhelhos com uma razão relativamente elevada de folhelho/ arenito. Os dados dimensionais e litológicos dos poços 9-PBi-5, Bi-1-BA, Pi-1-BA e CERB-IV, que atravessam essas unidades, indicam um valor de cerca de 3/2 para esta razão.

No Alto de Biritinga dos quatro poços perfurados para a Embasa, os três que atravessam principalmente a unidade $\mathrm{A}$ (poços E-02, E-03 e E-05) foram abandonados devido à elevada salinização de suas águas (A.M. Guerra 1982, comunicação verbal). Já o poço E-04, que está localizado nas proximidades da Falha de Biritinga e atravessa essencialmente a unidade B num trecho com menos ocorrência de folhelhos, fornece água quimicamente potável (Tab. 3).

$\mathrm{Na}$ área do baixo de Biritinga, o sistema aqüífero nos primeiros $200 \mathrm{~m}$ da superfície compreende as unidades B e C do Grupo Ilhas. A unidade A ocorre, neste bloco, abaixo de profundidades entre 350 e $400 \mathrm{~m}$ e contém água salinizada conforme indica o perfil de PE do poço Bi-1-BA. Os intervalos arenosos mais superficiais da unidade $\mathrm{C}$ correspondentes ao nível freático fornecem água salinizada, cuja concentração parece ligada à intensa evaporação. Os poços CERB-I, CERB-III e CERB-VIII isolam esses níveis superiores até profundidades da ordem de $25 \mathrm{~m}$ e explotam águas subterrâneas do sistema confinado com excelentes qualidades químicas. Por outro lado, os poços da Fazenda Lagoa e o E-06 localizados nas proximidades da falha de Biritinga pro- duzem águas salobras (Tab. 3). Trata-se, todavia, de poços rasos com menos de $100 \mathrm{~m}$ de profundidade, que parecem estar captando águas misturadas com a do lençol freático.

A definição do Alto Pau do Oco foi realizada pela identificação do topo da Formação Candeias no perfil elétrico do poço CERB-VI e da correlação dos perfis elétricos dos poços CERB-VI, CERB-IV, CERV-V e CERB-IX. A forte inclinação das camadas nesse bloco fez com que os poços CERB-VI e CERB-IV penetrassem através de unidades $\mathrm{B}$ e A, e os poços CERB-V e CERB-IX atravessassem as unidades $\mathrm{C}$ e $\mathrm{B}$. Todos os poços fornecem águas de excelente qualidade, embora para o poço CERB-VI se verifique um aumento sensível da salinidade com a profundidade.

Os blocos correspondentes ao Alto Fazenda da Serra e ao Baixo Olhos D'Água tiveram sua conformação estrutural definida em função dos dados geoelétricos, uma vez que não existem poços nessa zona. A correlação entre os modelos geoelétricos interpretados e a seqüência estratigráfica do Grupo Ilhas se fez com base na comparação dos valores de resistividades associados com cada bloco. Assim, os modelos de SE-10 e SE-11 apresentam um predomínio de níveis resistivos semelhantes àqueles obtidos sobre o Alto Pau do Oco, associados aos membros C e B, enquanto o substrato ligeiramente mais condutor $(60 \Omega \mathrm{m})$ foi correlacionado à unidade $\mathrm{A}$, com maior proporção de folhelhos. Sobre o Baixo Olhos D'Água o padrão de distribuição de resistividades é semelhante ao do Baixo de Biritinga, indicando a presença de possantes arenitos portadores de água doce a partir de $125-150 \mathrm{~m}$ de profundidade.

No Alto de Pataíba, o perfil composto do poço Pi-1-Ba indica sobre a Formação Candeias a ocorrência dominante da unidade A e uma pequena fração de unidade B, no topo. As sondagens elétricas realizadas nessa zona apresentam valores relativamente mais baixos para as resistividades dos arenitos e o perfil de PE do Pi-1-BA indica que esses arenitos estão saturados de águas salobras (Tab. 1).

O comportamento estrutural do Baixo de Pataíba é o menos claramente definido neste trabalho. Soares \& Pereira (1966) indicam que o rejeito da Falha de Pataíba é da ordem de $225 \mathrm{~m}$. Este dado, juntamente com os valores médios das espessuras das unidades do Grupo Ilhas definidos nios demais blocos, foi usado na construção desse trecho do perfil. Os dois poços perfurados pela CERB sobre esta

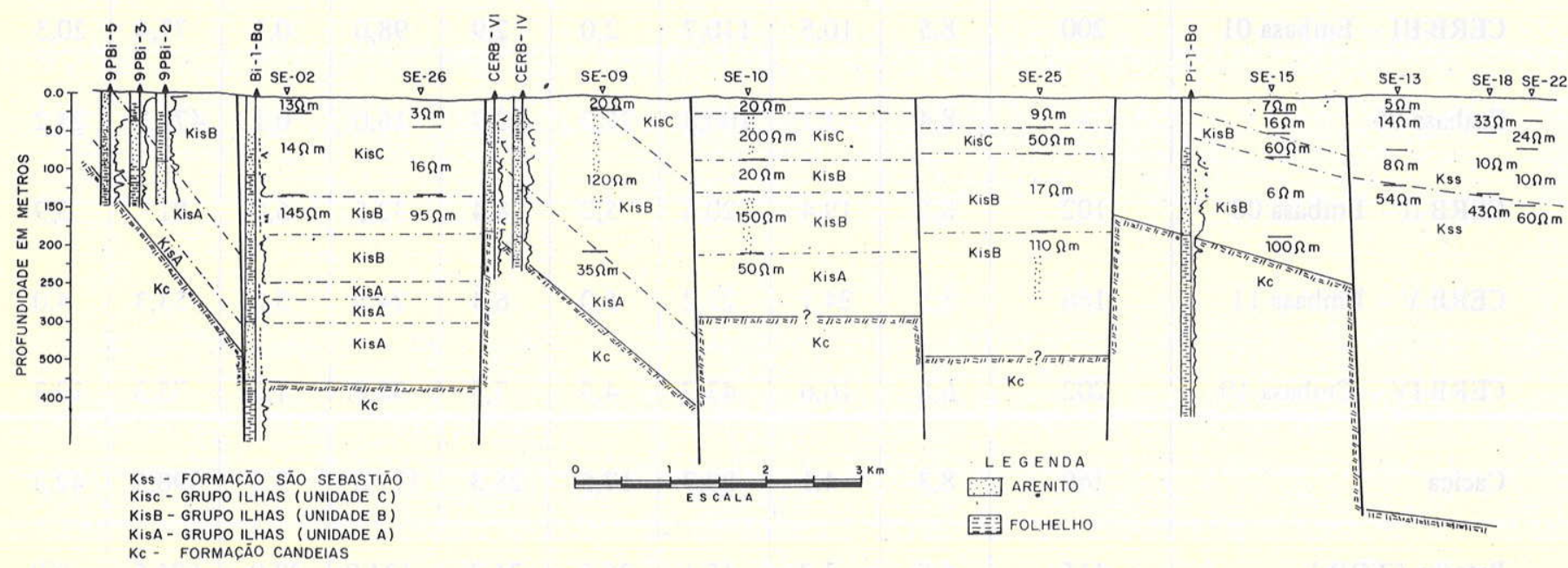

Figura 10 - Seção geológico-estrutural transversal através da área de Biritinga-Pataíba 
estrutura, até profundidades de cerca de $200 \mathrm{~m}$, fornecem águas com elevados teores de sais (Tabs. 1 e 3). Todas as sondagens elétricas executadas sobre esse baixo fornecem valores entre 30 e $60 \Omega \mathrm{m}$ para a resistividade dos arenitos da Formação São Sebastião, valores bem abaixo daqueles dos arenitos do Grupo Ilhas produtores de água doce (90-200 $\Omega \mathrm{m})$. Este fato sugere a ocorrência generalizada de água salobra na Formação São Sebastião a leste da Falha de Pataíba.

O fato de a água subterrânea, na região estudada, produzida por corpos de arenitos argilosos com elevada proporção de folhelhos intercalados, possuir, normalmente, teores de sais elevados sugere que o processo de salinização se relaciona tanto com a troca iônica realizada pelas argilas durante o fluxo da água como com a filtração de membrana pelas camadas de folhelhos. $\mathrm{O}$ próprio efeito de filtração iônica pode explicar o aumento da salinidade com a profundidade observado em alguns poços da área, conforme modelo sugerido por Lima (1983).

Além disso, a estruturação da seqüência estratigráfica em blocos falhados colocou lateralmente em contato unidades aqüíferas de permeabilidades diferentes conforme se infere de suas composições litológicas e, também, contendo águas de composições químicas diferentes. Desse modo, um fenômeno macroscópico de dispersão hidrodinâmica deve estar operando no sistema, que é mais efetivo quanto maior o contraste de permeabilidade entre os leitos postos em contato pelas falhas (Schwartz 1977). Provavelmente, este é o mecanismo responsável pela salinização da água da Formação São Sebastião a leste da Falha de Pataíba. Ali os aqüíferos menos permeáveis e altamente salinizados do Alto de Pataíba estão em contato direto com os arenitos bem mais permeáveis da Formação São Sebastião.

\section{CONCLUSÕES A análise dos perfis elétricos de poços e} a interpretação das sondagens elétricas verticais realizadas na região de Biritinga-Pataíba revelaram que os aqüíferos contidos nos grupos Ilhas e Massacará estão seccionados por falhas de gravidade que produziram uma sucessão de altos e baixos estruturais. Nas áreas de maior elevação, o Grupo Ilhas vem representado ou por sua unidade intermediária B ou pela unidade basal $\mathrm{A}$, ambas caracterizadas por uma maior proporção de folhelhos sobre arenitos. Nessas zonas é normal encontrar aqüíferos salinizados principalmente nas maiores profundidades, uma vez que nesses altos as interfaces de águas salobras estão a profundidades em geral menores que $150 \mathrm{~m}$. As zonas rebaixadas compreendem normalmente toda a seqüência do Grupo Ilhas, até sua seção superior mais arenosa (unidade C). Geralmente, nessas zonas, os arenitos das unidades $\mathrm{C}$ e $\mathrm{B}$ produzem águas de excelente qualidade e a interface de água salobra está mais profunda, além de $300 \mathrm{~m}$.

Os dados das sondagens elétricas permitiram também analisar a sucessão estratigráfica e a estruturação dos arenitos nos locais onde não há dados de poços pela comparação de seus parâmetros geoelétricos com os de blocos em que ambos os dados são disponíveis. A comparação entre perfis elétricos de poços com modelos geoelétricos derivados de sondagens centradas nos mesmos permite, também, distinguir camadas de arenitos argilosos ou com muitas intercalações de folhelhos de camadas espessas de arenitos saturados de água salobra.

Os principais mecanismos atuantes no processo de salinização da água após sua entrada no sistema aquífero confinado parecem estar relacionados com a ação de troca de íons realizada pelas argilas e a filtração iônica por membranas semipermeáveis que são seletivas de cátions, ao nível de cada bloco estrutural. Também a ação da dispersão hidrodinâmica ao nível mais regional parece processar-se pelas zonas de falhamentos, das quais a mais importante deve ser a Falha de Pataíba, por meio da qual se processa uma salinização generalizada da água do aqüífero São Sebastião.

Agradecimentos Os autores agradecem à Companhia de Engenharia Rural da Bahia (CERB) e à Petrobrás, pelo fornecimento das cópias dos perfis elétricos de poços usados neste trabalho. Ao eletrônico Carlos A. Portela, pelo planejamento e pela construção do sistema transmissor usado na execução das sondagens elétricas. Esta pesquisa foi financiada pela Financiadora de Estudos e Projetos (Finep) e pelo Conselho Nacional de Desenvolvimento Científico e Tecnológico (CNPq), e realizada sob a responsabilidade do Programa de Pesquisa e Pós-Graduação em Geofísica da Universidàde Federal da Bahia (PPPG/UFBa).

\section{REFERENCIAS BIBLIOGRAFICAS}

ALGER, R.P. - 1966 - Interpretation of electrical logs in fresh water wells in unconsolidated formations. Trans. SPWLA Seventh Annual Symposium: 246-270.

ANDERSON, W.L. - 1979 - Numerical integration of related Hankel Transform of orders 0 and 1 by adaptive digital filtering. Geophysics, 44(2):1287-1305.

ARAOUJO, M.B. - 1971 - Interpretação estrutural rasa dos prospectos de Biritingá e Fazenda Barroca da Onça. Salvador, Petrobrás-RPBA, Rel. Tec. 1396.

ARCHIE, G.E. - 1942 - The electrical resistivity $\log$ as an aid in determining some reservoir characteristics. AIME Tech. Paper 1422.

CERB - 1975 - Cadastro de poços tubulares do Estado da Bahia. Salvador, Companhia de Engenharia Rural da Bahia, Secretaria de Saneamento e Recursos Hídricos. (CERB 2. Vol. II).

CERB - 1980 - Cadastro de poços tubulares do Estado da Bahia. Salvador, Companhia de Engenharia Rural da Bahia, Secretaria de Saneamento e Recursos Hídricos. (CERB 1. Vol. VIII).

CERB - 1981 - Cadastro de poços tubulares do Estado da Bahia. Salvador, Companhia de Engenharia Rural da Bahia, Secretaria de Saneamento e Recursos Hídricos. (CERB 1. Vol. IX).
CERB - 1983 - Cadastro de poços tubulares do Estado da Bahia. Salvador, Companhia de Engenharia Rural da Bahia, Secretaria de Saneamento e Recursos Hídricos. (CERB 1. Vol. X).

DE WITTE, A.J. - 1957 - Saturation and porosity from electric logs in shaly sands. Oil and Gas J., $55(4): 89-95$.

FERREIRA, J.C. - 1965 - Hidrogeologia das bacias sedimentares de Tucano e Jatobá. Bol. Téc. Petrobrás, 8(1):57-75.

GHIGNONE, J.I. - 1979 - Geologia dos sedimentos fanerozóicos da Bahia. In: GEOLOGIA E RECURSOS MINERAIS DO ESTADO DA BAHIA; Textos básicos. Inda H.A.V. Ed. Secretaria das Minas e Energia, Salvador.

GHOSH, D.P. - 1971 - The application of linear filter theory to the direct interpretation of geoelectrical resistivity sounding measurements. Geophys. Prosps., 19(2):192-217.

GOUNDOUIN, M.; TIXIER, M.P. \& SIMARD, G.L. - 1957 - An experimental study on the influence of the chemical composition of electrolytes on the SP curve. J. Pet. Tec., 9(2): $58-69$.

LEITE, D.C. - 1964 - A cooperação da Petrobrás na solução do problema de água subterrânea para o Nordeste. Salvador, Petrobrás-RPBA. (Rel. Téc.). 
LIMA, O.A.L. \& RIBEIRO A.C. - 1982 - Caracterização hidrogeológica do aqüífero São Sebastião na área de captação do CIA, Bahia, usando perfilagens elétricas de poços. Rev. Bras. Geofis., 1(1):11-22.

LIMA, O.A.L. - 1983 - Filtração de membrana e a salinização de água subterrânea: Aplicação a aqüíferos das bacias do Recôncavo e Tucano. Rev. Bras. Geoc., 13(1):23-26.

LYNCH, J.L. - 1962 - Formation evaluation. New York, Harper \& Raw.

PATNODE, H.W. \& WYLLIE, M.R.J. - 1950 - The presence of conductive solids in reservoir rocks as a factor in electric log interpretation. Trans. Am. Inst. Min. Metall. Eng., 189:47-52.

SCHLUMBERGER - 1972 - Log Interpretation. Vol. I, Principles. New York, Schlumberger Ltd.

SCHWARTZ, F.W. - 1977 - Macroscopic dispersion in porous media: The controlling factors. Water Resour. Res., 13(4): 743-752.

SOARES, A.C.R. \& PEREIRA, E.B. - 1966 - Detalhe geológico do flanco sudoeste da Bacia de Tucano. Salvador, Petrobrás-RPBA. (Rel. Téc. 0950).
VIANA, C.F.; GAMA Jr., E.G.; SIMÕES, I.A.; MOURA, J.A.; FONSECA, J.R.; ALVES, J.R. - 1971 - Revisão estratigráfica da Bacia Recôncavo/Tucano. Bol. Téc. Petrobrás, 14 (3/4): 157-192.

WALTON, W.C. - 1970 - Groundwater resources evaluations. New York, McGraw-Hill.

WORTHINGTON, P.F. - 1977 - Influence of matrix conduction upon hydrogeophysical relationship in arenaceous aquifers. Water Resour. Res., 13(1):87-92.

ZOHDY, A.A.R. - 1965 - The auxiliary point method of electrical sounding interpretation and its relationship to the Dar Zarrouk parameters. Geophysics, 30 (4):644-660.
MANUSCRITO

Recebido em 11 de abril de. 1986 Revisão aceita em 3 de julho de 1986 